\title{
Kinetics of the Transfer of Protonated Triazines Across the water|1,2-dichoroethane Interface
}

\author{
Miguel Velázquez-Manzanares ${ }^{1, *}$, Judith Amador-Hernández ${ }^{1}$, Iliana M. de la Garza Rodríguez ${ }^{1}$, \\ Edith M. Colunga Urbina ${ }^{l}$ and Faustino Canseco Sánchez ${ }^{2}$. \\ ${ }^{1}$ Faculty of Chemical Sciences, Universidad Autónoma de Coahuila, Blvd. V. Carranza S/N, 25280 \\ Saltillo, Coahuila, México. \\ ${ }^{2}$ Institute of Biotechnology, Universidad del Papaloapan, Circuito Central 200, 68301 San Juan \\ Bautista Tuxtepec, Oaxaca, México. \\ E-mail: $\underline{\text { mvmiguel@ hotmail.com }}$
}

doi: $10.20964 / 110402927$

Received: 15 January 2016 / Accepted: 7 February 2016 / Published: 1 March 2016

\begin{abstract}
Kinetics of the transfer of protonated triazines across the water|1.2-dichloroethane interface by mean cyclic voltammetry and electrochemical impedance spectroscopy was studied. The transfer Gibbs energy $\left(\Delta G_{t,}^{o, w \rightarrow o}\right)$ and the apparent rate constants $\left(\mathrm{k}_{\mathrm{s}}\right)$ across the liquid-liquid interface for atrazine, ametryn, terbutryn and prometryn were evaluated. The results showed that hydrophobicity and the molecular size of these herbicides play an important role in the kinetics values. Thus the atrazine (smaller molecular dimensions) have larger $\mathrm{k}_{\mathrm{s}}$ value compared to the ametryn, terbutryn and prometryn (larger molecular dimensions). The explanation of this difference is in the structural ability of the molecule to protect the charged group which is the one responsible for transporting the current across the interface. The present study can be an important approach to help understand the permeation kinetics of molecules across biological membranes.
\end{abstract}

Keywords: ITIES, Triazines, Kinetic process, ion transfer

\section{$\underline{\text { FULL TEXT }}$}

(C) 2016 The Authors. Published by ESG (www.electrochemsci.org). This article is an open access article distributed under the terms and conditions of the Creative Commons Attribution license (http://creativecommons.org/licenses/by/4.0/). 